\title{
ASEAN-Australia Trade Relations by Stages of Processing: Comparative Research
}

\author{
Phuong Ha Nguyen, ${ }^{1 *}$ Long Mong Hoang, ${ }^{2}$ and Dung Duy Nguyen ${ }^{1}$ \\ ${ }^{1}$ Institute for Southeast Asian Studies, Vietnam Academy of Social Sciences, Vietnam \\ ${ }^{2}$ Ho Chi Minh City University of Foreign Languages and Information Technology, \\ Vietnam
}

DOI: https://doi.org/10.14710/jmsni.v4i2.7993

\begin{abstract}
Association of Southeast Asian Nations (ASEAN) and Australia became the Received: dialogue partner in 1974. Over 46 years of cooperation and development, June 4, 2020 ASEAN-Australia relations have achieved many good results, especially in recent years when two sides participate in several free trade agreements (FTAs) at bilateral levels and multilateral levels. In 2014, Australia and ASEAN formally became strategic partners, recognizing the importance of the relationship in building mutual benefits. Participation in FTAs and relationship upgrading has helped bilateral trade growth. In 2018-2019, Australia was the seventh-largest trading partner of ASEAN and ASEAN was one of Australia's top three trading partner, however, the two sides face many challenges such as the difficulties after the global crisis since 2009, the

Revised:

December 10, 2020

Accepted:

December 10, 2020

*Corresponding Author: nguyenhaphuong92@gmail.com "spaghetti bowl" phenomenon of joining many agreements at the same time. Thus, to solve these problems, the production and exports of comparative advantage goods by the stages of processing, including capital goods, raw materials, intermediate goods, consumer goods, to participate in an ideal regional supply chain are very important. Based on the comparative theory and supply chain perspectives, the revealed comparative advantage indexes (RCA) of ASEAN countries and Australia from 2009 through 2018 were used. From RCA comparision, the ideal effective supply chain distribution among ASEAN countries and Australia could be provided. Afterwards, through trade value comparison, the paper examined that ASEAN countries and Australia specialized in production by stages of processing. From the results, appropriate recommendations were provided to enhance the trade relations between ASEAN and Australia.
\end{abstract}

Keywords: Comparative Research; Stages of Processing; Trade Relations.

\section{Introduction}

After the global crisis in 2009, the world economy encountered many difficulties. Some economic powers have also tended to pivot their cooperation to the Asia-Pacific region. In this context, ASEAN countries and Australia found the solution to revive the economy by promoting trade relations with potential new partners other than traditional partners. At the same time, ASEAN-Australia-New Zealand Free trade Area (AANZFTA) was signed on 27 February 2009 in Hua Hin, Thailand. AANZFTA, which established to enhance the synergy among ASEAN, Australia, and New Zealand, is the deepest and broadest of the five free trade agreements between dialogue partners and ASEAN (Malcom Cook 2018). It was effective for Thailand on 12th March 2010; for Cambodia and Laos on 1st and 4th January in 2011 respectively; and for Indonesia on 10th January in 2012 (New Zealand's Ministry of Foreign Affairs and Trade 2012,2). The AANZFTA is the most comprehensive economic agreement concluded by ASEAN with its Dialogue Partners (ASEAN Secretariat 2009, iv). AANZFTA is also a "living agreement" because of the continuous development of built-in mechanisms to allow further liberalization and practical problem-solving over time (ASEAN Secretariat 2009, 3). It includes measures to improve business flow and promote cooperation in a wide range of economic sectors. Based on "the trade facilitation provisions and measures designed to provide greater transparency and certainty for companies doing business in the region" (ASEAN Secretariat 2009, 3), market access improvements are supplemented importantly. In other words, The 
AANZFTA is a comprehensive and single-undertaking free trade agreement that opens up and creates new opportunities for approximately 663 million peoples of ASEAN, Australia and New Zealand through rapid reduction and progress in eliminating tariff barriers. Thus, the AANZFTA is an opportunity for businesses to expand their investment and exports to make an effective supply chain in the region. In 2020, Australia will pledge to eliminate all tariffs, to take advantage of this, ASEAN countries need to determine which products have advantages to focus on producing and exporting to Australia.

Since ASEAN became a community in 2015, the ASEAN-Australia have become stronger when two ways appreciated the importance of promoting bilateral relations and upgrading a role as strategic partners. Australian Government affirmed in 2017 Foreign Policy White Paper that "Australia places a high priority on our bilateral relationships in Southeast Asia and on our support for ASEAN" and "elevated our commitment to ASEAN and enduring our ties with the countries of South-East Asia" (Australian Government 2017, 44). At the same time, some ASEAN countries also have supported Australia's participation in ASEAN. Indonesian President Joko Widodo suggested that Australia would help economic and political stability in the region if it was made part of ASEAN (Dobell 2018, 315). Even Malaysian Prime Minister Mahathir Mohamad expressed his approval for this membership invitation (Dobell 2018, 318).

Moreover, along with the AANZFTA, ASEAN and Australia also participate in some multilateral FTAs such as the Regional Comprehensive Economic Partnership (RCEP), a potential free trade agreement. Australia and some ASEAN countries including Brunei, Malaysia, Singapore, andVietnam participated in the Comprehensive and Progressive Agreement for Trans-Pacific Partnership (CPTPP). The matter becomes more and more complicated because ASEAN and Australia have simultaneously participated in FTAs at different levels and regulations, which has been described by Jagdish Bhagwati as a "spaghetti bowl effect" (Bhagwati 1995, 4). The "spaghetti bowl effect" is an phenomenon in trade economics where the increasing number of FTAs between countries slows down trade relations between them. This term makes an analogy between the tangling of spaghetti in a bowl with the tangling of different FTAs in a region. To sufficiently manage the complexity of overlapping commitments of FTAs, capacity building is a central strategy for developing countries (Majluf 2004, 16). To enhance the ability of FTAs utilization, developing countries in ASEAN should learn from developed countries to participate in regional production networks. The establishment of a supply chain based on the rational distribution of stages of processing products will solve the "spaghetti bowl" situation. Therefore, selecting the suitable stages of processing, which based on comparative advantage products, to participate in a suitable supply chain is necessary for that context.

Some researchers have published works relating to ASEAN economic relations and Australia. Robert Scollay and Ray Trewin (2006) presented a comparative analysis of CEPs/FTAs, mainly those completed or currently negotiated by Australia and New Zealand with ASEAN countries. Moreover, it also comprehensively evaluated the rules in the AANZFTA and provided suitable access to enhance the relationship between ASEAN, Australia, and New Zealand in the context of the AANZFTA. Jiro Okamoto (2014) researched the development of ASEAN-Australia economic relations since the 1970s in four different phases. According to the author's evaluation, in recent years, economic relations between ASEAN and Australia might have entered into a new phase because all countries had aimed for more liberalization through enhancing regional economic cooperation. Misa Okabe (2015) assessed the role of the AANZFTA in the specialization of exports to further enhance ASEANAustralia trade relations. The exchange of goods, materials, and transport equipment between Australia and Thailand had been strengthened thanks to bilateral FTAs. Trade-in agricultural products from Cambodia, Indonesia, and Vietnam seemed to be significantly increased by the AANZFTA. The results of this study implied that bilateral FTAs are often formed with major trading partners while multilateral FTAs provided opportunities for expanding trade with smaller trading partners. Therefore, to take advantage of commitments in the AANZFTA, Australia, and New Zealand had formed production networks within ASEAN.

Most of the research analyzed the general relationship in several aspects such as economic, social welfare, employment, and so forth, but in-depth studies on trade are modest. Besides, all of the studies above focused on the bilateral trade relations between ASEAN with Australia before 2010. Thus, the 
paper will address research gaps to provide the ideal effective supply chain distribution among ASEAN countries and Australia and examined that ASEAN countries and Australia specialized in production by stages of processing from 2009 to 2018. From that results, some recomendations could be provided. These are the novelty of the research paper.

David Ricardo proposed a hypothesis that a country tended to specialize in manufacturing and exporting comparative advantage goods under equal conditions. Trade between the two countries will be more efficient if each country exports goods that it has a comparative advantage (Krugman 2011, 12). The theory of comparative advantage assumes that each country will redirect specialization in producing goods that have comparative advantages when moving from self-sufficiency to trade with other countries. This happens due to the differences in technology and relative prices of the two commodities among countries. Because the comparative advantage theory assumes that transportation costs are zero, profits from exports will be greater than selling in domestic, trade flows will increase until the prices of goods are equal between countries. The increase in export prices will cause that country to focus on specializing the production of advantageous goods and export them to other countries. From there, companies seeking profit in each country will turn to produce and export the goods that the country has an advantage.

From supply chain perspectives, countries participating in the regional value chain will be most effective if they specialize in production, which is under their strengths. The improved manufacturing process and the benefits of preferential commitments in the trading bloc are also opportunities for the nation to participate in the global value chain through international investment. As a result, countries can promote their comparative advantage, learn advanced technology sources, and improve national competitiveness. This allows developing countries to join the value chain instead of building the whole chain themselves and have the opportunity in learning modern technology and management of developed countries (Baldwin 2011, 172 ).

Fragmentation of production processes along the value chain, or vertical specialization, helps countries to promote their production advantages (Bruhn 2014, 1). In other words, the structure of exported goods by the stages of processing will change towards the specialization when the trade becomes more liberal through participation in the global supply chain. Several developing countries, with access to global networks and access to advanced technological knowledge. With goods of higher quality, meeting international requirements, countries can balance production structure, aiming to export goods with higher value-added.

The objective of this study is to provide an ideal supply chain among ASEAN members and Australia based on revealed comparative advantage (RCA) and to assess on the trade of products by the stages of processing, in reality, to see if any adjustments should be made based on the competitive advantage to improve the ASEAN-Australia economic cooperation.

\section{Method}

To find the products in which a country has a comparative advantage, Balassa introduced the revealed comparative advantage (RCA) index in 1965. The formula for the RCA index is: RCA $=\frac{x I j / x I}{x a j / x a}$ In which: (i) $x I j$ is the exports of product $j$ by country I, (ii) XI is the total exports of country I, (iii) $\mathrm{Xaj}$ is the total exports of products $\mathrm{j}$ from the reference area (the world), (iv) Xa is the total export of the reference area.

RCA calculates goods in which a country has an advantage. It is defined as the ratio of a country's share of the products in the country's total exports to the share of world exports of the products in total world exports. A country is said to have a revealed comparative advantage if the value of the index exceeds 1 (one) and a revealed comparative disadvantage if the index's value is below 1 . The larger the difference between countries' RCA indices, the more suitable they are as FTA partners. (Plummer, Cheong, Hamanaka 2010, 38). This index calculates advantages by industry or commodity of a country. In addition, if the RCA index of the two countries in a trade bloc is different, the more those two countries are suitable and potential partners in the bloc. Thus, the paper-based on RCA indexes comparison between ASEAN's countries and Australia to find the comparative advantages by stages of processing. And using comparison methods in assessing the trade value. From 
there, appropriate policies can be issued to countries to specialize in manufacturing and exporting that industry.

This study used the data of RCA indexes and bilateral trade products by stage of processing, which including four steps to complete the final goods along the production chain, of ASEAN member countries and Australia. The data is taken from the Trade map and the Wits- World Bank. According to the World Bank, products classified by the stages of processing are capital goods, raw materials, intermediate goods, consumer goods (World Bank 2020) . Based on Tuovila (2020), each stage of processing are defined as follows: (1) Capital goods are "tangible assets that one business produces that is in turn used by a second business to produce consumer goods or services. Capital goods include tangible assets, such as buildings, machinery, equipment, vehicles, and tools that an organization uses to produce goods or services" (Tuovila 2020); (2) Raw materials are "materials or substances used in the primary production or manufacturing of goods. Raw materials are commodities that are bought and sold on commodities exchanges worldwide. Traders buy and sell raw materials in what is called the factor market because raw materials are factors of production as are labor and capital" (Banton 2020); (3) Intermediate goods are "products used to produce a final good or finished product-also referred to as a consumer good. Intermediate goods-like salt-can also be finished products, since it is consumed directly by consumers and used by producers to manufacture other food products. Intermediate goods are sold between industries for resale or the production of other goods. These goods are also called semi-finished products because they are used as inputs to become part of the finished product" (Investopedia 2020); (4) Consumer goods are "products bought for consumption by the average consumer. Alternatively called final goods, consumer goods are the result of production and manufacturing and are what a consumer will see stocked on the store shelf. Clothing, food, and jewelry are all examples of consumer goods. Basic or raw materials, such as copper, are not considered consumer goods because they must be transformed into usable products" (Investopedia 2020). From the theory and methods above, the research framework was produced as it is decribed in Figure 1.

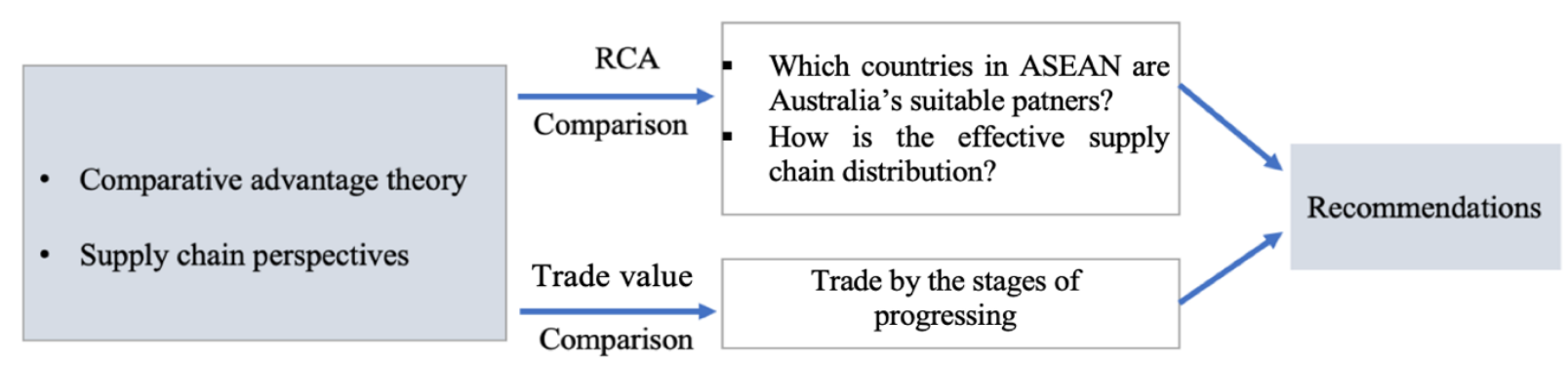

Figure 1. The Research Network.

Based on the comparative theory and supply chain perspectives with the assumption that there are no impact factors such as transportation cost, geographical distance, exchange rate, etc. The paper compared revealed comparative advantage indexes of ASEAN countries and Australia to find which country in ASEAN is Australia's suitable partners and the ideal effective supply chain distribution. After that, through trade value comparison, the paper examed if ASEAN countries and Australia specialized in production by stages of processing. From the results, appropriate recommendations were provided to countries to specialize in manufacturing and exporting to take advantage of the trading bloc and participating in the regional value chain.

\section{Overview of Bilateral Trade between ASEAN and Australia}

Total trade between ASEAN and Australia tended to increase from USD 46.6 billion in 2009 to USD 56.3 billion in 2019 despite the fluctuation. Thanks to the signing of the AANZFTA and stimulating cooperation policy, the bilateral trade significantly increased and reached the highest point at USD 71.4 billion in 2012 , leading to the recovery of the two-way trade after the global crisis. However, in 2015 and 2016, total export and import from Australia to ASEAN dramatically reduced to USD 51.3 
billion and USD 49.9 billion respectively due to the plunge of world oil prices, which was one of the top export and import goods among Australia and ASEAN countries. With the establishment of ASEAN Economic Community (AEC) in 2015, which promotes the economic synergy of ASEAN and dialogue partners including Australia, the bilateral trade rose to USD 62.7 billion in 2018, which makes Australia the seventh-largest trading partner of ASEAN and ASEAN was one of Australia's top three trading partners (ASEAN secretariat 2019, 2). Especially, in 2016, Australia's trade with ASEAN was greater than with the United States, it's a second-largest bilateral trading partner (Australian Government 2017, 143).

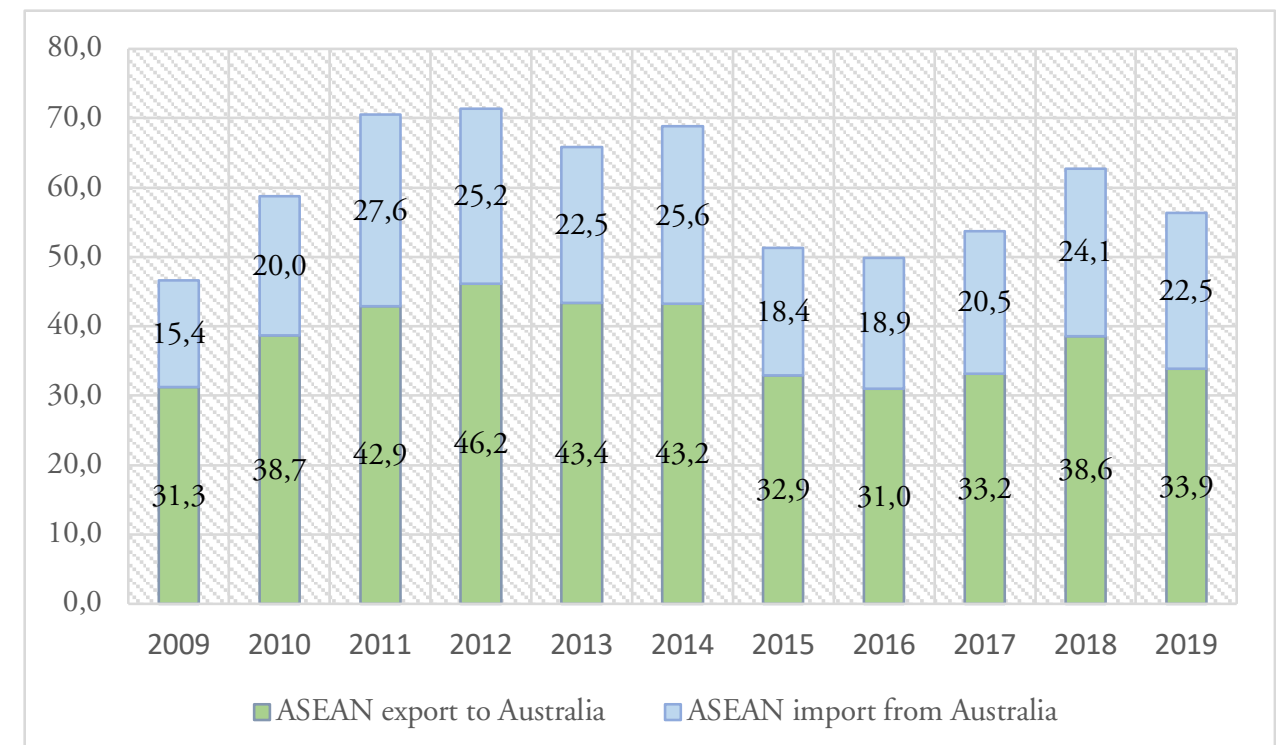

Figure 2. Bilateral Trade between Australia and ASEAN from 2009 to 2019 (Billion USD) Source: Trademap Database 2019.

Trade surplus belonged to ASEAN. Practically, net exports of ASEAN to Australia rose from USD 15.9 billion in 2009 to reach a peak of USD 20.9 billion in 2012 and 2013. This is due to the high demand for Australia for ASEAN exports after reducing the tariff of the AANZFTA. The trade surplus had been benefited ASEAN because ASEAN would take an active role in trade exchange with Australia. However, trade tended to be more balanced when the net exports of ASEAN to Australia decreased to USD 11.4 billion in 2017. This is an opportunity for ASEAN to balance its trade within the free trade area and with the rest of the world.

\section{Reveal Comprative Advantage Comparision by the Stages of Processing}

According to the RCA database of Wits- Worldbank, from 2009 to 2018, the ASEAN average RCA of consumer goods was 1.25, and RCA of raw material was 1.21 , which was higher than 1 . Thus, ASEAN had a comparative advantage in producing and exporting consumer goods and raw material. ASEAN had a comparative disadvantage in the capital and intermediate goods due to the moderate RCAs.

Australia's rich and diverse natural resources (Huệ 2016, 4). Australia has highly positive net exports in the international trade of iron ores, and also for copper, zinc, precious metals and aluminum ores and concentrates. In turn, these cashflows indicate Australia's strong competitive advantages under the ores, slag, and ash product category (Daniel Workman 2020). Thus, Australia had a remarkable comparative advantage in raw materials with RCA was 4.23. By contrast, Australia's RCAs of capital, consumer, and intermediate goods were only $0.13,0.46$, and 0.88 respectively. It means that Australia had a comparative disadvantage in the capital, consumer, and intermediate goods.

RCAs of ASEAN in consumer goods and capital goods were higher than in Australia. It means that compare to Australia, ASEAN had a comparative advantage in producing and exporting consumer goods and capital goods. Although ASEAN and Australia also had a comparative advantage in exporting raw materials, such as mineral fuels, mineral oils, plastic and rubber, etc. the RCA of 
Australia in raw materials was 3 units higher than ASEAN. The significant difference made Australia be an attractive exporter of raw materials to ASEAN. In opposition. Australia had higher RCA in intermediate goods compared to ASEAN. Thus, to effective bilateral trade, ASEAN should export consumer goods and capital goods to Australia. In addition, Australia should export raw materials and intermediate goods.

Table 1. RCA Comparison of ASEAN and Australia from 2009 to 2018

\begin{tabular}{lllll}
\hline Country & Capital Goods & Raw Materials & $\begin{array}{l}\text { Intermediate } \\
\text { Goods }\end{array}$ & $\begin{array}{l}\text { Consumer } \\
\text { Goods }\end{array}$ \\
\hline Australia & 0.13 & 4.23 & 0.88 & 0.46 \\
ASEAN & 0.8 & 1.21 & 0.85 & 1.25 \\
Brunei & 0.02 & 3.16 & 0.14 & 1.66 \\
Cambodia & 0.06 & 0.61 & 0.22 & 2.78 \\
Indonesia & 0.35 & 1.96 & 1.17 & 1.14 \\
Laos & 0.1 & 2.26 & 2.33 & 0.41 \\
Malaysia & 1.58 & 0.48 & 0.66 & 0.94 \\
Myanmar & 0.03 & 1.28 & 1.2 & 1.71 \\
Philippines & 2.06 & 0.67 & 0.43 & 0.53 \\
Singapore & 1.41 & 0.09 & 1.05 & 1.01 \\
Thailand & 1.4 & 0.51 & 0.89 & 0.96 \\
Vietnam & 1 & 1.05 & 0.45 & 1.37 \\
\hline
\end{tabular}

Source: Wits-Worldbank Database 2018.

Compare the RCAs among ASEAN's member countries and Australia from 2009 to 2018, Singapore was the most suitable partner with Australia because of the comparative advantage differences in all stages of progcessing. Thus, based on the aforementioned theory, trade between Singapore and Australia achieved a highest rank among ASEAN's countries. Brunei and Laos were the least suitable partners with Australia due to only one comparative advantage difference in consumer goods and intermediate goods respectively. The others had two comparative advantage differences in the stages of progcessing.

Regarding the classification of specific exchanged goods by the stages of processing based on the RCA's comparison, the Philippines was the most suitable exporter of capital goods to Australia, following by Malaysia, Singapore, Thailand, and Vietnam. Laos was the most suitable partner for exporting intermediate goods to Australia, following by Indonesia, Myanmar, and Singapore. Australia should import more consumer goods from Cambodia, Myanmar, Brunei, Vietnam, Indonesia, and Singapore. By contrast, related to the raw material, the most suitable importers of Australia are Singapore, Malaysia, Thailand, Cambodia, and the Philippines.

To solve the "spaghetti bowl" situation because of signing many overlapping FTAs, developing the effective production networks in the trading bloc is very important. From the results above, the ideal trade model and supply chain are provided in Figure 3.

\section{Trade Value Comparision by the Stages of Processing}

Regarding the stages of processing, in the period of 2009-2018, ASEAN mainly imported raw materials from Australia with $45.99 \%$, followed by intermediate goods with $34.22 \%$. Based on the theory of comparative advantage, provided by David Ricardo, Australia exported it's comparative advantage goods by the stages of progcessing to ASEAN made the two-way trade effective, especially in the context of the AANZFTA implementation in practical and globalization in general. On the contrary, the good that ASEAN exported the most to Australia was consumer goods with $42.91 \%$, which also were the comparative advantage good of ASEAN. In addition, ASEAN's export of capital goods accounted for the second proportion of 25.15\%. Thus, ASEAN and Australia also took advantage of specialization in producing and exporting comparative advantage goods. Moreover, the 
differences in export goods and import goods by the stages of processing made successful in the bilateral trade between ASEAN and Australia. This was matched with the ideal import and export model given in the previous section.

As mentioned above, based on the RCAs, Singapore was the most attractive trading partner of Australia. Through the trade value, Singapore accounted for $25.44 \%$ in the proportion of total trade between ASEAN and Australia, corresponding to USD 154.97 billion. This means that Singapore and Australia took advantage of exporting the comparative advantage products. The following countries are Thailand (24.16\%), Malaysia (20.73\%), Indonesia (15.03\%), Vietnam (9.68\%), the Philippines (3.29\%), which were all had two comparative advantage differences in the stages of progcessing. However, Cambodia and Myanmar were categorized into the second appropriate country group based on comparative advantage products, trade value propositions were modest with only $0.02 \%$. As a result, Cambodia and Myanmar did not success to capitalize on its strengths to promote trade with Australia. In another while, Brunei, which only one difference in comparative advantage products, still exported to Australia with a share of $1.22 \%$, ranked 7 th in the trade between ASEAN and Australia. Countries that had the smallest in trade value with Australia were Laos due to the most similarity in the structure of the stages of progress.

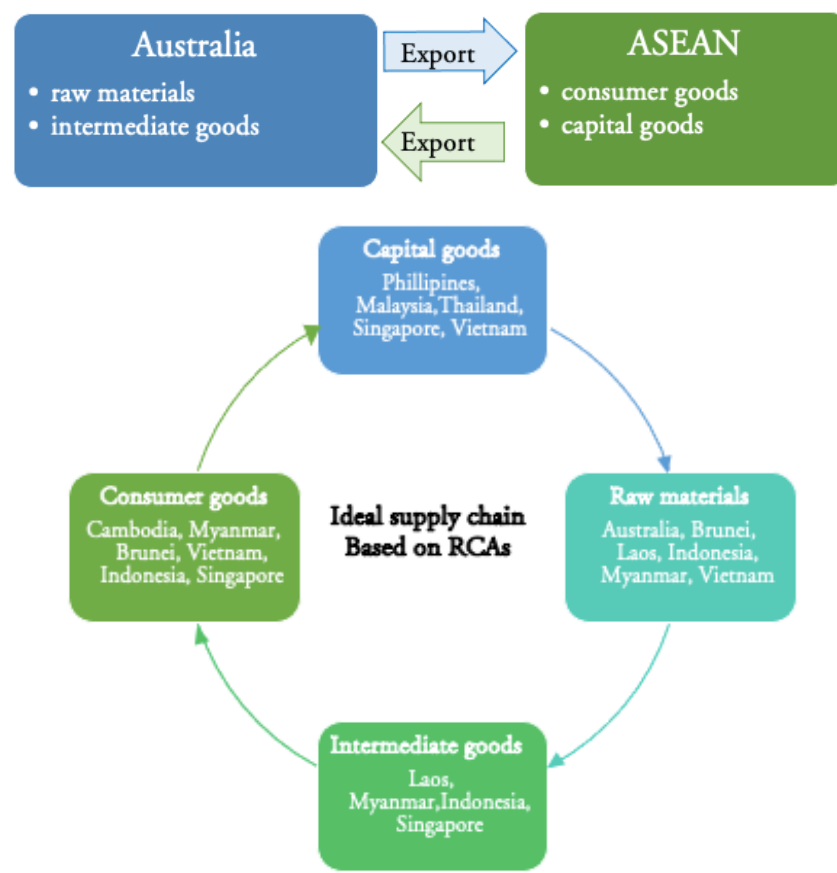

Figure 3. The ideal Trade Model and Supply Chain among ASEAN Countries and Australia

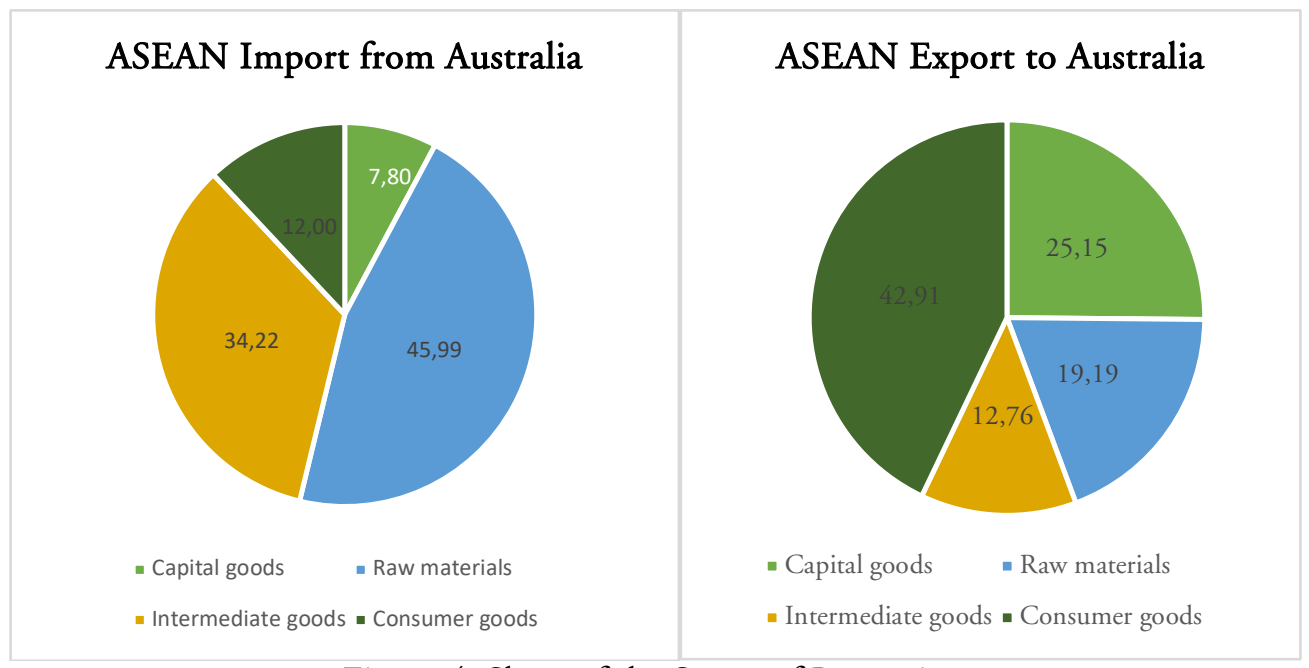

Figure 4. Share of the Stages of Processing in the ASEAN Trade with Australia from 2009 to 2018 (\%) 
Source: Wits-Worldbank Database 2018.

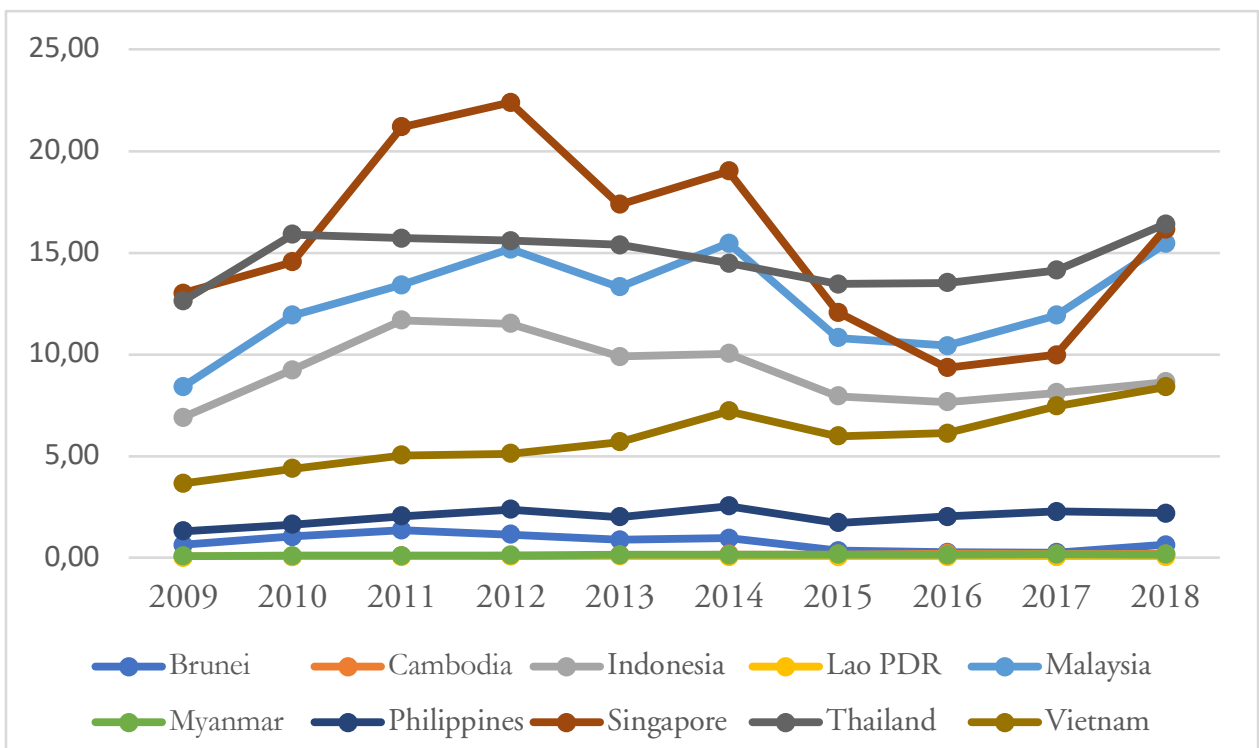

Figure 5. Bilateral Trade Value Between ASEAN Countries and Australia from 2009-2018 (USD billion) Source: Wits-Worldbank database 2018.

Table 2. Share of the Stages of Processing of Each ASEAN Country in Total Export to Australia from 2009 to 2018 (\%)

\begin{tabular}{lccccc}
\hline Country & $\begin{array}{c}\text { Capital } \\
\text { goods }\end{array}$ & $\begin{array}{c}\text { Raw } \\
\text { materials }\end{array}$ & $\begin{array}{c}\text { Intermediate } \\
\text { goods }\end{array}$ & $\begin{array}{c}\text { Consumer } \\
\text { goods }\end{array}$ & $\begin{array}{c}\text { Total export to } \\
\text { Australia }\end{array}$ \\
\hline Brunei & 0.07 & 99.82 & 0.03 & 0.08 & 100 \\
Cambodia & 0.33 & 0.01 & 4.15 & 95.51 & 100 \\
Indonesia & 12.14 & 37.33 & 23.48 & 27.06 & 100 \\
Laos & 6.96 & 4.33 & 62.50 & 26.21 & 100 \\
Malaysia & 20.57 & 37.29 & 12.04 & 30.10 & 100 \\
Myanmar & 0.99 & 41.80 & 12.44 & 44.77 & 100 \\
Philippines & 45.84 & 8.96 & 11.83 & 33.37 & 100 \\
Singapore & 13.23 & 0.51 & 10.52 & 75.74 & 100 \\
Thailand & 47.14 & 1.23 & 14.43 & 37.20 & 100 \\
Vietnam & 25.65 & 41.14 & 4.29 & 28.92 & 100 \\
\hline
\end{tabular}

Source: Wits- Worldbank Database 2018.

Based on the share of export value by the stages of progress, some countries in ASEAN could see the specialization in producing and exporting goods to Australia including Brunei, Cambodia, Singapore, Laos, and the Philippines. Related to capital goods, the Philippines was the most suitable partner in Australia, which means capital goods had the largest proportion of the export structure. This was also true in reality when capital goods accounted for $45.84 \%$ in the total export structure of the Philippines to Australia from 2009 to 2018. Similarly, Thailand took advantage of its competitive advantage through exporting capital goods to Australia (accounted for $47.14 \%$ in total export structure). Laos's specialization in exporting competitive products to Australia, being intermediate goods, was proved by the highest export rate with $62.5 \%$. Cambodia, Singapore, and Myanmar were the countries that had a comparative advantage in producing consumer goods. Thus, exported consumer goods of Cambodia, Singapore, and Myanmar to Australia accounted for $95.51 \%$ and $75.74 \%, 44.77 \%$ respectively in the total export structure of each country.

Nevertheless, not every country relied on comparative advantage to export. According to the comparative advantage theory, this would prevent the trade from reaching the most effective value, especially in the trading bloc. Specifically, compared to Australia, Malaysia had a comparative 
advantage in producing capital goods but it was only $20.57 \%$ lower than raw materials (37.29\%), and consumer goods $(30.1 \%)$. Based on RCA, Vietnam should export consumer and capital goods to Australia, however, these goods accounted for only $28.92 \%$ and $25.65 \%$ respectively, which were much lower than raw materials (41.14\%). For the case of Brunei and Indonesia, because two countries had a comparative advantage in producing raw materials, these accounted for the highest percentage in the export structure of the two countries (99.82\% and $37.33 \%$ respectively). However, Australia also had a comparative advantage in producing raw materials so to trade more efficiently, Brunei and Indonesia should export more comparative advantage goods compared to Australia.

Table 3. Share of the Stages of Processing of Each ASEAN Country in Total Import to Australia from 2009 to 2018 (\%)

\begin{tabular}{lccccc}
\hline Country & $\begin{array}{c}\text { Capital } \\
\text { goods }\end{array}$ & $\begin{array}{c}\text { Raw } \\
\text { materials }\end{array}$ & $\begin{array}{c}\text { Intermediate } \\
\text { goods }\end{array}$ & $\begin{array}{c}\text { Consumer } \\
\text { goods }\end{array}$ & $\begin{array}{c}\text { Total import from } \\
\text { Australia }\end{array}$ \\
\hline Brunei & 15.97 & 55.58 & 3.33 & 25.12 & 100 \\
Cambodia & 15.72 & 30.79 & 29.48 & 24.00 & 100 \\
Indonesia & 9.00 & 63.40 & 21.64 & 5.96 & 100 \\
Laos & 70.04 & 2.57 & 9.09 & 18.30 & 100 \\
Malaysia & 6.92 & 44.87 & 36.48 & 11.73 & 100 \\
Myanmar & 2.88 & 74.27 & 12.57 & 10.28 & 100 \\
Philippines & 5.78 & 59.56 & 19.10 & 15.55 & 100 \\
Singapore & 12.71 & 31.01 & 33.95 & 22.34 & 100 \\
Thailand & 4.70 & 40.95 & 46.97 & 7.38 & 100 \\
Vietnam & 2.82 & 50.63 & 40.11 & 6.44 & 100 \\
\hline
\end{tabular}

Source: Wits-Worldbank Database 2018.

In general, the actual import was effective because raw materials were the most products that ASEAN's countries imported from Australia. Nevertheless, Brunei had a comparative advantage in consumer goods but import much from Australia, which accounted for 25.12\%; Indonesia had more ability to produce intermedia goods than Australia but the import proportion was $21.64 \%$.

\section{Conclusion}

In general, trade relations between ASEAN and Australia in the period of 2009-2018 were quite effective with total trade tended to increase and be more balanced. Two- way trade tended to be more balanced when the net exports of ASEAN to Australia decreased. Moreover, ASEAN and Australia took advantage of specialization in producing and exporting comparative advantage goods. Specifically, Australia mainly exported raw materials and intermediate goods to ASEAN, which had RCA higher than the RCA of ASEAN. By contrast, ASEAN mainly exported its comparative advantage stages of processing, including capital goods and consumer goods, to Australia. Singapore was the most suitable partner with Australia because of the comparative advantage differences in all stages of processing. This was also true when Singapore was Australia's largest trading partner among ASEAN countries. Countries that had the smallest in trade value with Australia were Laos due to the most similarity in the structure of the stages of progress. Based on the share of export value by the stages of progress, some countries in ASEAN could see the specialization in producing and exporting goods to Australia including Brunei, Cambodia, Singapore, Laos, and the Phillippines.

However, the bilateral trade was not stable because of the high proportion of trading raw materials, and some countries in ASEAN could not take advantage of exporting its comparative advantage goods by the stages of progress. Specifically, Cambodia and Myanmar had 2 differences in RCA of products compared to Australia but trade value propositions were modest among ASEAN countries. In addition, not every country relied on comparative advantage to export including Brunei and Indonesia, Malaysia, Vietnam. 
Based on the given ideal supply chain and compared results above, some suggested adjustments. For the import from Australia, Brunei, Laos, Myanmar and the Phillippines should import more intermediate goods from Australia. For the export to Australia, some countries in ASEAN should change their structure of the stages of processing as follows: 1) With potential of producing consumer goods, Brunei should export more consumer goods to Australia to reduce the significant propotion of raw materials export; 2) Indonesia also should decrease in exporting raw materials. At the same time, Indonesia should focus more on exporting intermediate goods and consumer goods to Australia; 3) Malaysia should gradually shift export from raw material to capital goods to Australia; 4) Myanmar should export more intermediate goods to Australia; 5) Vietnam should reduce exporting raw materials to export more consumer goods and capital goods to Australia.

Therefore, with the restructuring by the stages of processing as suggestion and making suitable supply chain, the trade relations between ASEAN and Australia will be more effective and all country can take advantage of joining trading bloc and preferential of FTA in the region.

\section{References}

Abugattas, Luis. 2004. "Swimming in the Spaghetti Bowl: Challenges for Developing Countries under the 'New Regionalism'." Available at SSRN: https://ssrn.com/abstract=1280188 or http://dx.doi.org/10.2139/ssrn.1280188.

ASEAN secretariat, ASEAN Trade Database Preliminary Figures as of 13 May 2019.

ASEAN Secretariat. 2012. A Guide for ASEAN Business - ASEAN-Australia-New Zealand Free Trade Area. Jakarta: ASEAN Secretariat. https://catalogue.nla.gov.au/Record/4936391?from=list.

Balassa, Bela. 1965. "Trade liberalisation and "revealed" comparative advantage 1." The Manchester School33, no. 2: 99-123.

Baldwin, Richard. 2011. “Trade and industrialisation after globalisation's 2nd unbundling: How building and joining a supply chain are different and why it matters. Nber Working Paper Series. https://www.nber.org/system/files/working_papers/w17716/w17716.pdf.

Banton, Caroline. 2020. "Raw Materials." Accessed, November 30, 2020.

Bhagwati, Jagdish N. 1995. "US trade policy: The infatuation with FTAs."

Bruhn, Dominique. 2014. "Global value chains and deep preferential trade agreements: promoting trade at the cost of domestic policy autonomy?" Available at SSRN 2464136.

Cook, Malcolm. 2018. "ASEAN-Australia relations: The suitable status quo.” Accessed March 30, 2020.https://www.lowyinstitute.org/publications/asean-australia-relations-suitable-status-quo.

Database from: https://wits.worldbank.org/.

Database from: https://www.trademap.org/.

Dobell, Graeme. 2018. "ASEAN and Australia go to the summit." Australian Journal of International Affairs 72, no. 4: 314-321.

https://www.investopedia.com/terms/r/rawmaterials.asp\#:-:text=Raw\%20materials\%20are\%20mat erials\%20or,sold\%20on $\% 20$ commodities\%20xchanges\%20worldwide.

Huệ, Trương Thị Minh. 2016. "Hồ sơ thị trường Ôxtrâylia". https://vcosa.vn/Uploads/origin/HSTT-Oxtraylia-2016cap-nhat-T4-2016_oc_(1)20190603110858851.pdf.

Kenton, Will. 2020. "Intermediate good." Accessed November 30, 2020. https://www.investopedia.com/terms/i/intermediategood.asp\#:-:text=An\%20intermediate\%20good $\% 20$ is\%20a,to\%20manufacture\%20other\%2 Ofood $\% 20$ products.

Krugman, Paul R, and Maurice Obstfeld. 2011. International Economics: Theory \& Policy, Global Edition. Pearson Education: 9th edition.

New Zealand's Ministry of Foreign Affairs and Trade. 2020. The Agreement Establishing the ASEAN-Australia-New Zealand Free Trade Area. Wellington 5045, New Zealand.

Okabe, Misa. 2015. "Impact of free trade agreements on trade in East Asia." ERIA Discussion Paper Series 1: 48. 
Okamoto, Jiro. 2014. “Australia’s Economic Relations with ASEAN: Learning to Deal with the Evolving Organization.” In The Australia-ASEAN Dialogue, edited by Wood S.P., He B., 127-143. New York: Palgrave Macmillan.

Plummer, Michael G., David Cheong, and Shintaro Hamanaka. 2011. Methodology for impact assessment of free trade agreements. Asian Development Bank.

Tuovila, Alicia. 2020. "Capital Goods.” Accessed November 30, 2020.

https://www.investopedia.com/terms/c/capitalgoods.asp\#:-:text=Capital\%20goods\%20are\%2

0physical\%20assets, used\%20to\%20make\%20finished\%20goods.

Worldbank. 2020. "Product Group." https://wits.worldbank.org/Product-Metadata.aspx?lang=en. 